\title{
Sōteria [salvation] in Christianity and Ụbandu [wholeness] in Igbo traditional religion: Towards a renewed understanding
}

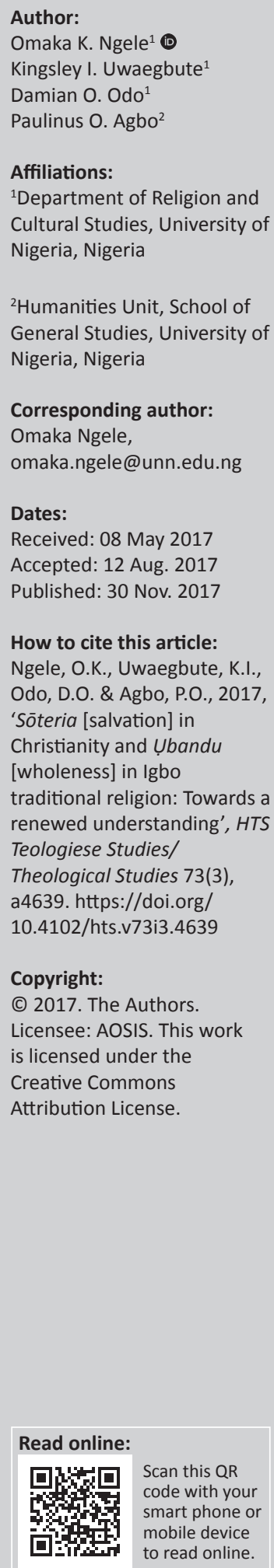

\begin{abstract}
This study affirmed the fact that there is the idea of salvation in all religions whether revealed or indigenous. This applies categorically to Christianity and Igbo traditional religion (ITR). The basis for this comparative study of sotteria [salvation] and $u b a n d u$ [wholeness] in both Christianity and ITR is to juxtapose the two religions' intrinsic value and distinctive heritage for wider readership and shared knowledge. The aim of this study is to carry out a critical comparative study of the concepts of sōteria and $u b a n d u$ in both Christianity and ITR locating their nexus and point of departure. This study is therefore comparative in approach. The methodology applied to this effect is, firstly, the lexical analysis which involves a critical study of the uses of soteria in the New Testament Greek Bible. Secondly, in the context of ITR, our discussions on $u b a n d u$ and sōteria as form and expression of doctrine of salvation call for the application of a phenomenological lens; through this, we used oral interviews as source of primary data. This study discovered that both Christianity and ITR define soteria and $u b a n d u$ from a physical standpoint to include God's providence, protection and preservation. It is on eschatological experience of soteria and $u b a n d u$ that both religions have points of nexus and divergences. It deciphers the fact that eschatological experience of sōteria in Christianity is highly dependent on the belief in Jesus and his mediatory role which can be either accepted or refused by humans. Eschatological experience of ubandu in ITR is ancestorhood which is highly dependent on the use of coercive force through the enforcement of omenala [Igbo moral codes] in ensuring its experience on the part of practitioners when they transit to the ancestral world.
\end{abstract}

\section{Introduction}

Salvation is a very important aspect of religion. This stems from the fact that the quest for salvation is at the heart of all religions (Adelakun 2011). This study agrees with Goring (1995:455) that salvation relates to 'the deliverance of human kind by religious means from sin or evil, the restoration of human beings to their truest state and attainment of eternal blessedness'. This understanding is hung on the belief that all religions strive towards restoring humans to their truest state which leads to eternal blessedness. This restoration could be a 'saving' from all things that constrain both the human body and soul in forms of poverty, physical dangers, sicknesses, sin and its effect, hell and any other thing that militates against the well-being of humans in the present life and the life to come. The usages of sotteria in the New Testament therefore have multifaceted meanings (Marshall 2004).

In this regard, the Christian religion has the message of salvation littered in its Holy Book. In Christianity, especially the New Testament, the message of salvation is at the heart of its theology. In the New Testament, salvation is referred to as sōteria (Alland et al. 1993). Sōteria is a Greek word that is mostly translated as 'salvation' in the English language and in its most accepted usages in the New Testament connotes deliverance, preservation, safety and salvation (Alland, Alland, Karavidopoulos et al. 1993).

Like Christianity, the Igbo traditional religion (ITR) has the notion of salvation. As a part of African traditional religion (ATR), ITR has at its heart the promise of salvation for its practitioners. Critical studies on ATR have shown that the religion has a strong belief in salvation. The study agrees with Akrong (2011) that ATR is 'a religion of salvation and wholeness' because 'a careful analysis shows an emphasis on this worldly [sic] salvation and wholeness' as the 'raison d' etre' of African Traditional Religion'. This is a fact this study's field work's findings on salvation in ITR show. 
Because the Igbo traditionally believe that life here on earth encompasses an intricate Web of interaction between the physical and spiritual, humans' earthly life can be enhanced or diminished depending on how this interaction is maintained. This informs the aim of the Igbo traditionalists to preserve life here on the earth in its fullness through the maintenance of the above-described interaction that equally has effect in the afterlife. This, to a great extent, shows that it is a core belief in ITR that acceptance or rejection in the ancestral world is, in part, the effect of humans' interaction with the spiritual world while alive. Being accepted into the ancestral homeland is the ultimate eschatological experience of $u b a n d u$ [salvation] in ITR, just as achieving the best life can offer here on the earth is an important part of the experience of $u b a n d u$ as salvation for the practitioners of the religion.

This brief analysis shows that although both Christianity and ITR have belief in salvation, their ideas of salvation greatly differ. This validates Adelakun's (2011) claim that 'although salvation is a common feature of all religions, its meaning is different from one religion to another and from one people to another'. This idea resonates equally well with Brand (2002:495), who quips that 'salvation is often taken as a key to the very heart of all religions and views of life and a fruitful basis for comparisons between them'. These are definitive of the fact that the idea of salvation differs among religions. On this premise, therefore, in the study, we attempt a critical study of the idea of soteria and $u b a n d u$ in Christianity and ITR.

This study is aware of the existence of scholarly works on the concept of salvation generally in ATR (Maimela 1991; Mbiti 1975; Ngong 2009; Schmidt 2006). However, it will be an overgeneralisation to overlook the peculiarities there are among traditional religious beliefs and practices in Africa which, by implication, warns of the inadequacies in over-reliance on this general treatment of salvation in ATR as being always applicable in all traditional religious settings when considered independently. The aim of this study is therefore to carry out a critical comparative study of the concepts of soteria and $u b a n d u$ in both Christianity and ITR locating their nexus and point of departure through a phenomenological lens. This study is comparative. It is partly driven by lack of a comprehensive study by available scholarly works on the idea of salvation in ITR. The methodology applied to this effect is, firstly, the lexical analysis ${ }^{1}$ which involves a critical study of the uses of soteria in the New Testament Greek Bible. Secondly, in the context of ITR, our discussions on $u b a n d u$ and sōteria as form and expression of doctrine of salvation call for application of a phenomenological approach; through this, we used oral interviews with practitioners of ITR. The data elicited from the practitioners of ITR interviewed were descriptively presented.

1.The lexical approach is a methodology adopted in biblical exegesis which aims a understanding words, idioms and grammatical forms of a language. For more on this, see Gorman (2006:13)

\section{Sōteria [salvation] in Christianity: The New Testament perspective}

Although salvation is a well-known term in the Old Testament, its Old Testament understanding may not really agree with that of the New Testament. As a part of what the Christian idea of salvation entails has a tie in with that of Old Testament, the Old Testament therefore forms our departure point in the study of salvation in Christianity here. In the Old Testament, salvation is etymologically derived from the Hebrew stem yash. According to Horne (1980:221), yash means 'to be wide, roomy'. From this stem, salvation is written (transliterated) as yêsh $\hat{u}^{\prime} \hat{a}$ or yêshûa in Hebrew (Brown, Driver \& Briggs 2014:447). From Jewish and Old Testament perspectives, yêsh $\hat{u}^{\prime} \hat{a}$ or yêshûâ denotes deliverance, by a stronger being, from factors which constrain and confine. These include deliverance from disease, trouble, enemies, adversity and captivity. This is why salvation in Jewish and Old Testament perspectives is considered from a physical standpoint as it deals with, mostly, the deliverance of humans from things that constrain their physical well-being. This is corroborated by McKenzie (2014:1308) who pointed out that the Hebrew word yêsh $\hat{u}^{\prime} \hat{a}$ [salvation] as used in the Old Testament 'often occurs in contexts where it refers to deliverance by military means' and also 'deliverance from any threat to life or integrity of person'.

Some of the Old Testament ideas of salvation were, however, incorporated by the writers of the New Testament. For instance, Jesus apart from being concerned with spiritual salvation from sin was also involved in deliverance of the demon-possessed, healing the sick and giving bread to the hungry and the poor as part of His mission, hence fulfilling his messianic manifesto stated in Luke 4:18. Notwithstanding this, there is a great line separating both Old and New Testaments' understandings of salvation. In the New Testament, the Greek feminine noun sotteria is used for salvation. According to Foester and Fohrer (1971:1132), sōteria in classical Greek usage connotes the following ideas: saving - especially from serious peril; keeping - especially keeping something alive; benefiting - that is, being a recipient of an act or action; preservation - that is, of inner being or nature. In the New Testament, sōteria and its other usages like sōterios and sōterion occur about 42 times. ${ }^{2}$ In these occurrences, sōteria connotes deliverance, safety and also preservation (Thayer 2015:612). ${ }^{3}$ Soteria, equally, is used to denote salvation in a technical biblical sense of the messianic age ${ }^{4}$ and salvation as the present and future possessions of Christians. ${ }^{5}$

2.The number given here is not absolute because it depends on the translation of a Bible version. However, we took our data from New American Standard Bible (NASB) translation. Viewed 08 January 2017, from http://www.biblehub.com/ Greek/4991.html

3. Examples of usages of sōteria to mean deliverance, safety and preservation in the New Testament Greek Bible are found in Luke1:71, Acts 7:25, Hebrews 11:7, Luke 19:9,2 Peter 3:15 and Acts 27:34.

4.See Matthew 1:21, John 4: 22, Acts, 13:47, Romans 11:11, 2 Thessalonians 2:13; 2 Timothy 3:15, Hebrews 2:3; 6:9 and Jude 1:13.

5.Examples include 2 Corinthians 1:6, 2 Corinthians 7:10, Philippians 1:19, Lik Luke 1:77, Romans 13:11, 1 Thessalonians 5:8 and 1 Peter 1:9. 
The verbal sense of sōteria which is sōzo is used in the New Testament in mostly three ways which, according to Marshall (2004:998), mean: (1) to rescue a human or something from danger and to restore a human or something to a previous state of safety, (2) a therapeutic sense that denotes the process of making someone well again after being sick and (3) to cause someone to experience divine salvation which has been overstressed to the neglect of the other two meanings of sōteria in the New Testament.

The above critically shows that sōteria as salvation in the New Testament has both physical and spiritual dimensions. This is perhaps why Barclay (1964:270-272) calls New Testament salvation 'total salvation'. According to Adelakun (2011:28), New Testament salvation 'saves a man, body and soul'. On this lies the uniqueness of salvation in the New Testament. Barclay (1964) goes on to present concise, unique and distinctive characteristics of New Testament usages of sōteria and $s \bar{o} z \bar{o}$ from tripartite angles which are that:

- Sōteria is the intention of God and the reason of Jesus' coming. Jesus' mission therefore was to save humans from sin and its effects and other physical constraints.

- It can be refused by humans. This is because it is not part of God's character to force people to accept salvation through Jesus Christ.

- The place of Jesus in God's sōteria in the New Testament is indispensable. Take away Jesus and his role and sōteria cannot be achieved.

Historically, from Christian or Judaist viewpoints, it was part of God's intention to have a 'perfect' relationship with humans after creation. But this was not to be as humans, represented by Adam and Eve, rebelled against God through disobedience as seen in Genesis 3. Multiplication of sin was what followed this rebellion; estrangement and alienation from God was also the direct consequence of humans' multiplication of sin. Hence, in this fallen state, according to New Testament theology of soteria, God sent Jesus to offer humans salvation through his life and work. This was also a part of God's desire to restore the broken relationship that existed between humans and him prior to Jesus' coming. It is thus in this regard that the death of Jesus on the cross is taught in New Testament as the apex of God's quest to save sinful humans, as Adeyamoh (2006:1379) puts it:

The critical component in Christianity is the cross, where the sin factor was dealt with. God made Jesus to be sin though he was sin less so that anyone who believes in him can receive God's forgiveness and be saved. (2 Cor 5:21)

Similarly, Min (1989) also stressed this idea by writing that 'at the heart of Christian faith is the reality and hope of salvation in Jesus Christ. Christian faith is faith in God of salvation revealed in Jesus of Nazareth'. As we had discussed, the use of sōteria as salvation in the New Testament also includes divine saving of humans. This is exactly the point the above assertions allude to. This divine salvation of humans therefore was only made possible through Jesus' death on the cross and those who accept God's salvation through Jesus are saved and preserved for God during the consummation of time. This therefore shows that having a relationship with Jesus through belief in him also ensures salvation in Christianity.

However, being that it is not in God's character to force people to accept salvation through Jesus, rejection of this salvation will have eschatological consequences. One of such consequences of this rejection of God's offer of salvation through Jesus will be condemnation and rejection in the kingdom of God (cf. Jn 3:18). There is also the lack of mercy at the judgement seat of God, and finally casting into hell of all that entirely rejected Christ's salvation work of the cross (cf. Rev 20: 12-15).

\section{Igbo traditional religion: Towards a description}

We deem it necessary to, at least, describe the traditional religion of the Igbo people as this will help give direction to an understanding of the idea of salvation in the religion. ITR is the traditional religion of the Igbo people commonly in the South-Eastern part of Nigeria. Presently, the Igbo make up five states in Eastern Nigeria which include Enugu, Ebonyi, Imo, Anambra and Abia. The scope of our discussion on Igbo religion is strictly limited to Igbo of these states.

Because a robust body of literature exists on ITR, we present here a synthesis of the core beliefs and practices of the religion. At the heart of Igbo, religion is the belief in spiritual beings of which the highest is called Chukwu which may be translated as the big or high God. Chukwu as the high God of the Igbo is believed to have been the creator of the world and all things in it. The creative work of Chukwu, as Uchendu (1965:95), (Ifesieh1989:25), Ugwu and Ugwueye (2004:32) and Onwu (2002) highlighted, is seen in the various names attributed to him (Chukwu). These include Chineke [Creator God], Chi-Okike [God who creates], Chukwu Abiama and Agalabaji Igwe [the pillar that holds the sky] and Ezechiteoke [King spirit that is the creator].

Next in rank after Chukwu are the divinities believed to be Chukwu's creatures and agents. Among the divinities, Ala [the Earth goddess] stands out because it is regarded as the most powerful divinity. Ala is the guardian of Igbo morality and also a very merciful mother because of her provisions and intercession for her children. Other Igbo divinities include Anyanwu [sun god], Amadioha [god of thunder sky], Kamalu [god of Thunder] and so on. Closely following, the divinities are the ancestors who are the most loved spiritual beings of all in ITR. The ancestors are the dead and departed elders of families, Umunna [a group of people who trace their origin to a common ancestor who is usually a male originator of such group of people] and villages. Hence, they are called Ndichie, Ndibunze, Ndinnyaha and so on. The ancestors have cults where they are usually venerated. These cults are usually represented as onunna, akpanna and onuchi and are always situated in front of the Obi [sitting room] of Igbo traditionalists. Ancestors are venerated by living Igbo family 
members through sacrifices and prayers. Amidst these sacrifices and prayers, living family members ask their ancestors for protection, providence and general well-being. So long as the ancestors are venerated through sacrifices and prayers, they remain 'viably living' and able to perform tasks expected of them by their family members.

Following the ancestors are the oracles. Even with the socalled modernity, the presence of oracles is still felt in most Igboland. Different Igbo towns and villages have their local oracles associated with them (Agbo 1994:25-26). Also, the Igbo names for oracles differ greatly; for the Nsukka Igbo, for example, oracles are called mma; most Anambra people call oracles Alusi, while the Igbo from Imo call oracles Ihu agzu or agbara. Igbo oracles usually have dedicated priests who minister to them. The oracles, we must also say, are believed to be agents of Chukwu, the Igbo high God.

There are also myriad spirits which include both the good and bad ones that the Igbo believe in Ifesieh (1989:38-39). These myriad spirits are equally believed to have the capacity to harm or affect human lives. Among these spirits is the chi, the personal god of every Igbo person, which connects him or her with Chukwu. Chi can be male or female and also controls people's destinies here on the earth. ${ }^{6}$ Other beliefs and practices of ITR include the belief in moral rectitude as enshrined in the Omenala or Omenani, which is the Igbo code of conduct. ITR also believes in practice of medicine popularly called $\rho g w u$ and also, in sacred personages who include the priests, diviners and medicine men.

Being that ITR has a belief in myriad spiritual beings (gods), contentions really exist among scholars regarding the technical name for this religion. ${ }^{7}$ A critical study of the religion by the researchers based on belief and worship system shows that ITR has elements of monotheism, polytheism and pantheism. The Igbo believe in Chukwu, the high God, which is central to the religious belief system despite the presence of other gods. This, in some technical sense, gives the Igbo religion some semblance of monotheism. The religion also has pantheistic elements because it identifies Chukwu's activities with the things he created. Moreover, the Igbo traditionally believe that the earth is Chukwu's footstool; this is a typical pantheistic religious outlook. Mostly, ITR is polytheistic as the Igbo religious world is alive with many gods which the people worship.

\section{The Igbo traditional world view}

We agree with Ifesieh (1989:20) that world view has 'its operational core as the sum total of ideas which an individual or individuals within any group have about the world and how it operates'. For the Igbo, the sum total of their views about the world and life generally is very much shaped by

6.We argue that C.M. Ezekwugo's Chi: The true God in Igbo Traditional Religion Alwaye: Pontifical Institute of Philosophy and Theology, is by far the best literature on the concept of Chi in ITR.

7.By 'contentions' over technical name for Igbo religion, we mean the religion is monotheistic, polytheistic, pantheistic and so on. their religion. This seems factual because the Igbo like all other African clans are notoriously religious (Mbiti 1969). The Igbo, as we have shown, believe in Chukwu, the high God believed to have created the world. Hence, the Igbo conceive of the world in terms of the sky, better called eluigwe. Eluigwe is believed to be the abode of Chukwu. Next is the earth which is called $u w a$ and is the place where humans and other creatures including the spirits dwell. Man is conceived by the Igbo not to be capable of living independent of his physical environment. Therefore, their world view is also shaped by the physical environment such as mountains, trees, animals, rivers, streams and caves, which, in most cases, form totems and sacred places of worship. There is also the alammuo, the world beyond, which the Igbo believe to be a part of the world. Alammuo could mean the land of the spirit which is mysteriously called the world beyond; this is why it is also regarded as the land of the ancestor.

Humans, being the centre of Chukwu's creative work, must maintain all spiritual relationships with their physical environment, and mostly the spiritual world. Of course, in ITR, the physical and spiritual worlds are closely interwoven, although the spiritual is sacred and the physical is considered 'mundane'. By implication, the physical world and that of the spiritual world intercept, hence both greatly interact. This interaction notwithstanding, there is still a detachment between these two worlds (physical and spiritual). Ngele (2008) affirmed that the meeting point between the two worlds is technically known as axis mundi, with the divinities as mediators. Paramount of concern to the Igbo is to maintain both the spiritual and physical relationships required of them.

Because the earth where humans dwell is also inhabited by bad spirits which can diminish human life, the maintenance of relationship with the spiritual world is very important to the Igbo so as to engender the human life here on the earth. We must note that maintenance of spiritual relationship used in this context usually takes the form of sacrifices, prayers, libations and strict observance of the omenala. From these discussions, it is therefore clear that Igbo world view is very much spiritually charged; life on earth is therefore seen as a complex whole involving constant interaction with the spiritual world, physical world and the alamuo, the world beyond.

\section{Ubandu in Igbo traditional religion: A critical appraisal}

There is, without doubt, a dearth of literature on salvation which we conceptualise as $u b a n d u$ in the context of ITR. However, in the course of this research, we found two related works on salvation in ITR which are deemed necessary for review here. As far as we know, Osuji's (1977) was the first work performed on Igbo traditional experience of salvation. Osuji's analyses tilted towards Igbo experience of salvation through ancestorhood and its eschatological gain of reincarnation. Osuji's work also pointed towards salvation as ancestorhood being experienced by deceased Igbo adult 
male genders who met the required criteria. This is seen in the fact that Osuji's work contained ideas which seemed to suggest that only deceased Igbo adult male genders qualify as ancestors. Closely following Osuji's work was that of Okorocha (1982). The cruxes of Okorocha's findings rested on Igbo traditional experience of salvation through Ezi-ndu [viable life]. The basis of this salvation, as Okorocha showed, lies in moral rectitude through strict observance of ofo na ogu as encoded in the Omenala [Igbo moral codes of conduct]. The eschatological aspect of $E z i-n d u$ as salvation to the Igbo according to Okorocha is the Ahamuefula [may my name not be forgotten] which is the Igbo idea of continuity of earthly life.

The findings of these studies are apt but they capture, in part, Igbo experience of salvation. While, for example, we agree that ancestorhood and its eschatological gain of reincarnation is an important aspect of Igbo experience of salvation, Osuji's work seemed to have overlooked the worldly manifestations of salvation in ITR. This shows that salvation in ITR is not only an eschatological spiritual experience but also a 'worldly' experience. With regard to Okorocha's findings on Igbo experience of salvation, we agree that Ezi-ndu [viable life], which is dependent on strict observation of omenala [Igbo codes of conduct], is a form of salvation for the Igbo, traditionally, in the present life. However, Okorocha's presentation of ahamuefula, the Igbo idea of continuity of life, as eschatological salvation leaves much to be desired.

Admittedly, ahamuefula portrays the Igbo idea of continuity of earthly life. But Okorocha overlooked the fact that based on Igbo naming customs, ahamuefula is a name generally given to male children and, as most Igbo clans are patriarchal, it follows that if we see eschatological salvation among the Igbo as ahamuefula, doubts are then raised about the holistic nature of salvation in ITR. By implication, this means that only the male gender, at the exclusion of the female gender, experiences eschatological salvation through ahamuefula. Against this idea, we stress the holistic nature of eschatological salvation in ITR which is not all that gender discriminating. Equally we add, as indicated in the aim of this study, that there are traces of the interaction of Christian idea of salvation on modern-day ITR conception of salvation which are sometimes neglected in scholarly discourse. In this regard, we therefore discuss below the idea of salvation in ITR.

Being that the Igbo see life on earth as constituting a complex web of interaction between the three spheres we had discussed (spiritual world of Chukwu, physical and the world beyond), their experience of salvation is world-affirming, personal and physical, relationship-based, holistic and eschatological and involves the use of coercion in its (salvation) achievement. Because the aim of the maintenance of all spiritual relationships through fulfilment of religious sacrifices, prayers, obligations and moral rectitude through observance of Omenala is directly aimed at ensuring humans' well-being here on the earth, the Igbo experience of salvation is, firstly, world-affirming. This maintenance of all spiritual relationships, we must add, most times is achieved through the use of sanctions that are usually called Nso ala (taboos). In this sense, there is an element of the use of force in ensuring the maintenance of all spiritual relationships in ITR which leads to achieving salvation.

In the foregoing, it therefore means that salvation in ITR is experienced in concrete visible forms. These include general well-being and provisions of life in forms of good health, prospering households, bountiful harvests, large number of children who continue family lineages, peace and harmony and longevity. Agbo, when interviewed on 06 January 2017, argued that these are the products of human relationships with spiritual beings which include the ancestors and Chukwu most especially. Agbo goes further to tell us that this relationship is paralleled to the idea of soteria in Christianity where Jesus is seen as a restorer of humans' broken relationship with God. While there is no concept of original sin in ITR like that of Christianity which necessitated humankind's fall and Jesus' coming to restore humankind's relationship with God as discussed in the study, there is the concept of sin in ITR which is seen in the violation of the laid down laws, taboos and totems and traditional laws. This is seen as a community-based offence against Chukwu and the ancestors. It therefore necessitate sacrifices to the divinities and ancestors, especially the earth goddess Ani as a mediator. This is meant to appease Chukwu the supreme God in ITR. Therefore, we affirm that like Christianity achieving salvation in ITR is heavily relationship-based just as has been indicated above in the case of Christianity (Eze and Nwokoro, pers. Comm., 23 October 2016). This therefore means that achieving salvation in ITR is tied to having a good relationship with the ancestors and Chukwu. Two other informants we interviewed pointed out their belief that salvation in ITR is based on humans' relationships with the spiritual beings. This idea that salvation in ITR is relationship-based indeed constitutes the nexus between the Christian idea of salvation and ITR concept of $u b a n d u$ in modern time as found out in the course of this research.

Equally, the Igbo, traditionally believing in the inseparability of humans from their community, also conceive of this worldaffirming salvation as extending to the community level. Hence, communal peace and harmony, prosperity and general thriving of the community are all manifestations of salvation. All these are assurances to the Igbo traditionally of the fact that Chukwu, the divinities and the ancestors are happy, and therefore, blessing both the people and the community at large. We therefore call this world-affirming salvation in ITR $u b a n d u$, the Igbo word for wholeness of life. The achievement of $u b a n d u$ is of paramount importance to the Igbo.

On the other hand, $u b a n d u$ in ITR also has a very personal physical aspect. This relates to achieving physical well-being after a period of deteriorating health. The Igbo, as we have shown, believe in the services of sacred personages which include the medicine personalities. These medicine 
practitioners are called dibia in Igbo language and are experts in the concept of ogwu [traditional medicine]. The intricacies of the practice of $g$ gwu are beyond the scope of this research but it mostly involves the uses of roots, herbs and divination to cure human ailments. Traditionally, when the Igbo fall sick, the services of the dibia are contracted. But the Igbo, according to Omeroha (traditional title usually given to trado-medical practitioners) Asadu, traditionally believe that some strange ailments are the product of displeasure of some spiritual beings with the sick; in this regard, it is very important that divination is used to find out the particular spiritual being who has been offended before treatment of some ailments can be effective. Hence, Igbo experience of ubandu as salvation also amounts to restoration of failing health which is very much personal to the victims of such failing health.

There is also the eschatological Igbo experience of $u b a n d u$ as salvation. We agree strongly with Agbo (1994) that the Igbo religion has eschatological character because its practitioners:

believe in a future state of life, in the immortality of souls, in existence of a place of bliss in the hereafter for the good which they call Eligwe (heaven), and in abode of misery after this life for the wicked which is called Oku-mmo Hell-Ala Ojo. (p. x)

However, we strongly disagree with Agbo's point about the existence of heaven and hell in Igbo religious world view. It is most certain that the idea of heaven and hell in ITR is still part of the influence of Christianity on the practitioners of Igbo religion. An Attamah (priest) of Idenyi deity in Nru Nsukka told the researchers in an interview on 04 September 2016 that to the Igbo traditionally, only two worlds exist after death which is the world of the ancestors and that of the akalogoli [restless spirits]. We also add that non-existence of hell in ITR also manifests in the belief that all wrong doings by practitioners are believed to be punished here on the earth. If by sheer luck, the wrong doer escapes punishment, then his family and descendants must inherit the punishment. This therefore punctures any argument about a place of torment called hell in Igbo religious thought.

It is therefore Igbo traditional belief in eschatology that makes their experience of $u b a n d u$ as salvation eschatological as defined in terms of ancestorhood. We are of the opinion that in ITR, both male and female genders become ancestors so long as they meet all the criteria. Against the conventional belief that only deceased adult male genders qualify as ancestors (as we have shown in Osuji's work and that of Okorocha whose work tilted towards Ahamuefula), we strongly stress here that this belief is not always sustained. If, for example, Igbo naming customs, which are still sustained in modern times, depict deceased female family members as being able to reincarnate as females' names like nnenna (a female reincarnate of one's deceased mother) nneochie or nnenne (a female reincarnate of one's grandmother) suggest, it then follows that deceased female family members become ancestors; this is why they are believed to be able to reincarnate. This shows that eschatological salvation in ITR is holistic, experienced by both male and female genders. This is in pure contrast to both Osuji and Okorocha's idea of ahamuefula as eschatological experience of salvation in ITR.

These observations having been made, we say that ancestorhood, of course, is the highest end every traditional Igbo religious practitioner strives for after death. In fact, to the traditional Igbo religious practitioner, ancestorhood is the best form of salvation one can hope for. It is to them the truest form of eternal rest and bliss which elevates them to the level of 'super human'. Also, ancestorhood remains the best experience of salvation to the Igbo traditional religious adherent because of its gains which include chances of reincarnation and veneration by living family members.

However, we found that in recent times, ancestorhood as eschatological salvation in ITR is being likened to the Christian idea of being eschatologically saved into the kingdom of God through belief in Jesus during the end of time. According to Iheonu (pers. comm., 02 September 2016), both eschatological salvation in Christianity and ITR point towards the direction of eternal, blissful 'rest'; as such, both religions' ideas of spiritual eschatological salvation relate with each other. But on the issue of how the dead becomes eschatologically saved through entering the blissful world of the ancestors, on the one hand, and also reincarnates back into families left behind, on the other hand, which is not sustained in Christian idea of eschatological salvation, Iheonu offers us no clear explanation. To him, it is a matter of religious belief which cannot be proven through subjection to academic inquiry. After all, Iheonu claims that belief in eschatological salvation of being saved into the kingdom of God at the consummation of time through belief in Jesus does not need be subjected to academic enquiry for it to make sense to Christians. This likening of ancestorhood as eschatological salvation to Christian idea of eschatological salvation through being saved into the kingdom of God at the consummation of time is a pure nexus of Christianity and the ITR's idea of salvation.

\section{Sōteria [salvation] in Christianity and $U$ bandu in Igbo traditional religion: points of convergence and divergence}

Our analysis has shown that there is a strong belief in sōteria and $u b a n d u$ which is salvation in both Christianity and ITR. While sōteria as salvation in Christianity has many aspects, our discussion revealed that it encompasses physical deliverance in forms of healing of sicknesses and illness, deliverance from enemies and dangers and general providence in life. These resonate well in Igbo traditional religious experience of $u b a n d u$ as salvation. This is an important area of convergence as well as nexus of the idea of salvation in both Christianity and ITR. Also, the idea that salvation is relationship-based (in Christianity, this is achieved through belief in Jesus as restorer of broken relationships and in ITR this is tied in with having a good 
relationship with the spiritual beings which include the ancestors and Chukwu) resonates well in both Christianity and ITR.

Conversely, the Christian technical idea of soteria as the coming of the messianic age as initiated by Jesus Christ finds no place in the Igbo traditional religious idea of $u b a n d u$. This is where both Christian and Igbo traditional ideas of salvation differ greatly. While the eschatological aspect of soteria as salvation in Christianity has a direct link with the belief in Jesus as the saviour of humans, which can be accepted or rejected by humans, this is not the case with ITR. Of course, ITR has no knowledge of Jesus Christ and his salvific role in Christian salvation history. As such, ITR has no place for Jesus in its eschatological experience of $u b a n d u$ as salvation and also has an element of the use of force in ensuring the maintenance of all spiritual relationship with the appropriate spiritual quarters through the ancestors which ensures that salvation is achieved. It is also on this premise that there is a great deal of difference between Christian and Igbo traditional ideas of the 'fate' of humans after they have experienced eschatological salvation. In Christianity acceptance of God's sōteria through Jesus can be accepted by humans and leads to being accepted in the Kingdom of God which can be equated with being accepted in heaven. In contrast, in ITR, acceptance in the ancestral world is the best form of eschatological salvation a practitioner can experience. Similarly, the idea of hell, which Christianity presents as being the direct consequence of humans rejecting sōteria through Jesus, also has no appeal to Igbo traditional experience of $u b a n d u$ in its eschatological understanding. Although as we have shown, ancestorhood as eschatological experience of $u b a n d u$ in ITR is presently being likened to Christian idea of eschatological salvation through belief in Jesus, to the traditional Igbo religious practitioners, the consequence of not being eschatologically saved through ancestorhood, is the akalogoli, which, as we have discussed, are the dead restless spirits that did not make it to the ancestral homeland.

\section{Conclusion}

This study has significantly affirmed the fact that because God, who is the ultimate reality, is mostly located in all religions, whether revealed or traditional religion, it follows that salvation is found in almost all religions. This applies categorically to both Christianity and ITR. However, the understanding of sōteria and ubandu as salvation in Christianity and ITR is not the same. In contemporary underpinning, the idea of $u b a n d u$ which not only replicates salvation as well as wholeness has been established as a major nexus of the Christian idea of soteria as salvation. Both Christianity and ITR ideas of salvation have physical and eschatological dimensions. The physical dimension, which marks a major similarity in both religions' ideas of salvation, includes physical deliverance from enemies and sicknesses, safety, longevity, prosperity, peace and harmonious living. On the other hand, it is on the mediatory role of Jesus in the eschatological salvation of humanity which is conceived as ancestorhood in ITR that underscores the major difference in the salvation that both between Christianity and ITR.

\section{Acknowledgements Competing interests}

All authors equally contributed to the writing and research of this article.

\section{Authors' contributions}

O.K.N., K.I.U., D.O.O. and P.O.A. equally contributed to the research and writing of this article.

\section{References}

Adelakun, A., 2011, A theological reflection on Mbiti's conception of salvation in African Christianity, viewed 09 November 2016, from http://www.nobleworld. biz/images/Adelakun.pdf

Adeyamoh, T. (ed.), 2006, 'Ideas of salvation in other religions', in Africa Bible Commentary, p. 1379, Word Alive, Nairobi.

Agbo, D.J.U., 1994, Igbo Traditional Religion, vol. II, Chinedu Press, Nsukka.

Akrong, A., 2011, An introduction to African traditional religions, viewed 08 January 2017, from http://www.africawithin.com/religion/intr-to-atr.html

Alland, B. , K. Alland, J. Karavidopoulos, C.M Martini \& B. Metzger ., 1993, The Greek New Testament (With Dictionary), Duetsche Bibelgesellshaft, Stuttgart.

Barclay, W., 1964, New Testament word, SCM, London.

Brand, G., 2002, Speaking of fabulous ghost, Peter Lang, New York.

Brown, F., Driver, S. \& Briggs, C., 2014, The Brown - Driver, Briggs Hebrew and English lexicon, Hendrickson Publishers, Peabody, MA.

Foester, W. \& Fohrer, G., 1971, 'Sozo, Soteria, Soter, Soterios', in G. Friedrich (ed.) Theological dictionary of the New Testament, vol. II, pp. 1132-1140, W.M.B. Eerdmans, Grand Rapids, MA.

Gorman, M.J., 2006, Elements of Biblical Exegesis, Hendrickson, Peabody, MA.

Goring, R. (ed.), 1995, 'Salvation', in The Wordsworth dictionary of beliefs and religions, p. 455, Wordsworth Editions, Herefordshire.

Horne, C.M., 1980, 'Salvation', in M.C. Tenney (ed.), The Zondervan pictorial encyclopedia of the Bible, p. 222, Zondervan Publishing House, Grand Rapids, MI.

Ifesieh, E.I., 1989, Religion at the grassroots (Studies in Igbo Religion), Fourth Dimension Publishers, Enugu.

Maimela, S., 1991, 'Religion and culture: Blessings or curses?', Journal of Black Theology in South Africa 5(1), 1-15.

Marshall, H., 2004, 'Salvation', in D.G. Reid (ed.), The IVP dictionary of the New Testament, pp719-724 Inter Varsity Press, Leicester.

McKenzie, J.L., 2014, 'Aspects of Old Testament thought', in R.E. Brown, J.A. Fitzermeyer \& R.E. Murphy (eds.), The New Jerome Bible Commentary, pp. 12841314, Bloomsbury Publishing Company, London.

Mbiti, J.S., 1969, African religions and philosophy, Heinemann, London.

Mbiti, J.S., 1975, Introduction to African Traditional Religion, Heinemann, Lusaka

Min, A.K., 1989, Dialectic of salvation: Issues in theology of liberation, State University of New York Press, New York.

Ngele, O.K., 2008, 'The quest for African Christology: Towards a re-definition of Jesus in African context and faces', Nsukka Journal of Religious Studies 2(1), 59-71. C.O.T. Ugwu (ed.).

Ngong, D.T., 2009, 'Salvation and materialism in African theology Studies', World Christianity 15(1), 1-21. https://doi.org/10.3366/E135499010900032X

Okorocha, C., 1983, 'Salvation in Igbo religious experience: Its influence on Igbo Christianity', PhD thesis, University of Aberdeen.

Onwu, E.N., 2002, 'Uzo ndu na Eziokwu: Towards understanding of Igbo traditional religious life and philosophy', Ahiajoku Lecture Series, viewed 10 February 2017, from https://www.ahiajoku.com/2002/

Osuji, C., 1977, The concept of salvation in Igbo Traditional Religion, Urbanian University Press, Rome.

Schmidt, G., 2006, Evil and salvation in African Religion and Christianity, viewed 05 February 2017, from http://comboni.de/literatur/schmidt_gregor_evil_and_ salvation.pdf

Thayer, J.H., 2015, Thayer's Greek-English lexicon of the New Testament, Hendrickson, Peabody, MA.

Uchendu, V.C., 1965, The Igbo of southeast Nigeria, Holt, Rinehart and Winston, New York. Ugwu, C.O.T. \& Ugwueye, L.E., 2004, African Traditional Religion: A prolegomenon, Merit International Publications, Lagos. 